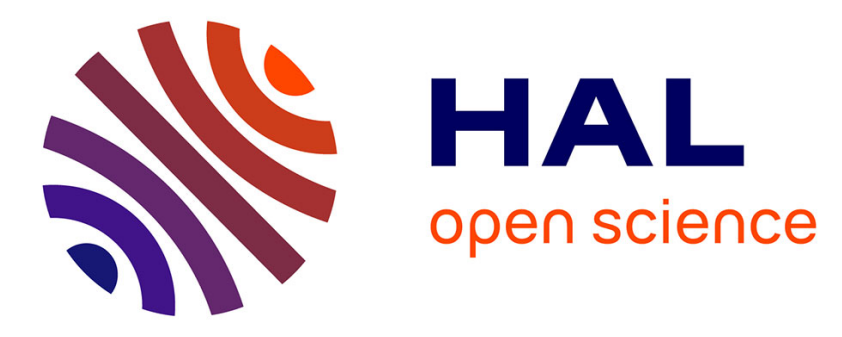

\title{
First evidence of the pore-forming properties of a keratin from skin mucus of rainbow trout (Oncorhynchus mykiss)
}

Virginie Molle, Sylvie Campagna, Yannick Bessin, Nathalie Ebran, Nathalie Saint, Gérard Molle

\section{To cite this version:}

Virginie Molle, Sylvie Campagna, Yannick Bessin, Nathalie Ebran, Nathalie Saint, et al.. First evidence of the pore-forming properties of a keratin from skin mucus of rainbow trout (Oncorhynchus mykiss). Biochemical Journal, 2008, 411 (1), pp.33-40. 10.1042/BJ20070801 . hal-00478828

\section{HAL Id: hal-00478828 \\ https://hal.science/hal-00478828}

Submitted on 30 Apr 2010

HAL is a multi-disciplinary open access archive for the deposit and dissemination of scientific research documents, whether they are published or not. The documents may come from teaching and research institutions in France or abroad, or from public or private research centers.
L'archive ouverte pluridisciplinaire HAL, est destinée au dépôt et à la diffusion de documents scientifiques de niveau recherche, publiés ou non, émanant des établissements d'enseignement et de recherche français ou étrangers, des laboratoires publics ou privés. 


\section{FIRST EVIDENCE OF THE PORE-FORMING PROPERTIES OF A KERATIN FROM SKIN MUCUS OF RAINBOW TROUT (ONCORHYNCHUS MYKISS).}

\section{Virginie Molle $^{1 *}$, Sylvie Campagna ${ }^{2,3^{*}}$, Yannick Bessin ${ }^{2,3}$, Nathalie Ebran ${ }^{4}$, Nathalie Saint $^{2,3}$ and Gérard Molle ${ }^{2,3^{\ddagger}}$}

${ }^{1}$ Institute of Biology and Chemistry of Proteins, University of Lyon, CNRS, Lyon, France.

${ }^{2}$ CBS, UMR 5048 CNRS, University of Montpellier I, 34090 Montpellier, France.

${ }^{3}$ U 554 INSERM, University of Montpellier I, 34090 Montpellier, France.

${ }^{4}$ Faculty of Medicine, Laboratory of Solid Tumour Genetics, Nice University Hospital, Nice, France.

Running title: Channel activity of trout type II keratin.

Keywords: Recombinant keratin, channel activity, fish defense, bilayers.

‡Address correspondence to: Dr Gérard Molle, Centre de Biochimie Structurale, UMR 5048 CNRS, UMR 554 INSERM, 29 rue de Navacelles 34090 Montpellier, France, Tel 33467417 912; Fax 33467 417 913; E-Mail: molle@cbs.cnrs.fr

* These authors contributed equally to this work 


\section{SUMMARY}

The epidermis of fish is covered with a layer of mucus which contributes to the defence of the species against parasites, bacteria and fungi. We have previously extracted glycoproteins from various mucus samples from fish and have shown that they present pore-forming activities well-correlated with strong antibacterial properties (Ebran et al. Biochim. Biophys. Acta (2000) 1467, 271-280). This study focuses on the $65 \mathrm{kDa}$ glycoprotein Tr65 from the trout Onchorhynchus mykiss. Enzymatic digestion of Tr65 yielded a fragment pattern with strong homology to that of trout type II cytokeratin. Sequence analysis of the cDNA clone obtained by PCR confirmed this homology. We thus constructed a plasmid to overproduce the recombinant Tr65. We extracted and purified this recombinant Tr65, using it for multichannel and single-channel experiments in azolectin bilayers. Our results with recombinant Tr65 confirmed the pore-forming properties already shown with native antibacterial Tr65. These findings offer new insight into the function of keratin proteins present in various mucosal surfaces of animals and human beings. 


\section{INTRODUCTION}

The skin mucous layer and epidermis are important in fish defence as they are the first sites of interaction between the host and potential pathogens. Within these layers are many antimicrobial compounds involved in innate immunity of the fish [1-3]. These non-specific microbicidal compounds are of critical relevance for fish as their adaptive immune system is less sophisticated than those of mammals and amphibians [4, 5], and is not fully effective in young fry [6]. Moreover, it has been proposed that innate immunity tends to replace specific immunity at low temperatures [7, 8]. Therefore, innate immunity is assumed to be more important for fish than for other endothermic vertebrates [2]. A variety of antibacterial proteins are present in the mucus of various fish species (for review see: $[1-3,9,10]$ ), including complement factors, lectins, and enzymes, e.g. lysozyme (also called muramidase), alkaline phosphatase and proteases. The surface mucosa of fish also contains a broad range of antimicrobial peptides, e.g. pardaxin from Moses sole fish (Pardachirus marmoratus) [11, 12], pleurocidin from winter flounder (Pleuronectes americanus) [13] and grammistins from Grammistes sexlineatus and Pogonoperca punctata [13-16], and histone-derived peptides, e.g. parasin-I from catfish (Parasilurus asotus) [17], oncorhyncin II from rainbow trout (Oncorhynchus mykiss) [18, 19] and hipposin from Atlantic halibut (Hipoglossus hippoglossus L.) [20]. Novel antibacterial factors will probably be identified in the future, as isolation and characterisation of defence substances from the epidermal layer of fish are relatively recent events. We have previously reported the isolation of several antibacterial glycoproteins from the epidermal mucus of carp, tench, eel and rainbow trout skin secretions [21, 22]. The present investigation aimed to identify one of these proteins (with a molecular mass of $65 \mathrm{kDa}$ ) from the skin mucus of rainbow trout (Oncorhynchus mykiss). This protein subsequently named Tr65, was purified from mucus samples and its gene was cloned. Analysis of internal sequences of Tr65 indicated that it significantly matched the trout Oncorhynchus mykiss type II epidermal keratin E1 (GenBank accession number AJ272369). We produced recombinant keratin in E. coli and purified it from inclusion bodies. Conductance experiments carried out with the recombinant protein yielded the same results as those observed with the protein extracted from mucus, confirming the identification of the protein. This is the first report showing that a protein from the keratin family has poreforming activity. 


\section{EXPERIMENTAL PROCEDURES}

\section{Protein purification}

The Tr65 protein was purified from epidermal mucus of rainbow trout (Oncorhynchus mykiss) as previously described [21]. Briefly, hydrophobic proteins were extracted from the mucus with a Ringer buffer containing 1\% (w/v) lithium dodecyl sulphate and were separated by SDS-PAGE. The protein band of interest $(65 \mathrm{kDa})$ was excised from the gel and then electroeluted with the Biotrap system (Ceralabo). Tr65 was also analysed by 2D electrophoresis. $20 \mu \mathrm{g}$ of protein was precipitated by trichoro-acetic acid and resolubilized in an IEF buffer of $5 \mathrm{M}$ urea, $2 \mathrm{M}$ thiourea, 0.5\% (w/v) amidosulfobetaine-14 (ASB14), $2 \mathrm{mM}$ tributyl phosphine, $10 \mathrm{mM}$ dithiothreitol, 2\% (v/v) carrier ampholytes (pH 3.5-10; Sigma) and $0.025 \%$ (w/v) Coomassie blue G 250 (Sigma) [23] (final volume, $400 \mu \mathrm{L}$ ). The firstdimension gel separation was carried out with Immobiline Dry Strips NL (18 cm, pH 3-10NL, Amersham Pharmacia Biotech, Uppsala, Sweden). IEF was carried out using an IEF cell apparatus (Bio-Rad) as follows: 50V for $12 \mathrm{~h}, 250 \mathrm{~V}$ for $15 \mathrm{~min}, 3 \mathrm{~h}$ of a linear increase to 10 $\mathrm{kV}$ and $10 \mathrm{kV}$ (1mA constant) for $10 \mathrm{~h}$ for a total of $105.6 \mathrm{kVh}$. The second dimension was obtained by SDS-PAGE using a $12 \%$ (w/v) polyacrylamide gel (width, $16 \mathrm{~cm}$; length, $20 \mathrm{~cm}$; thickness, $0.75 \mathrm{~mm}$ ). After migration, proteins were visualized by silver staining.

\section{Determination of carbohydrates and sialic acid groups}

The Immuno-Blot kit for the detection of glycoproteins from Bio-Rad (Hercules, CA) was used to detect the presence of carbohydrates and sialic acids. Following SDS-PAGE of the samples, the gels were transferred onto nitrocellulose membranes. After washing $(10 \mathrm{mn})$ with $30 \mathrm{ml}$ of PBS (9 mM sodium phosphate, $27 \mathrm{mM} \mathrm{NaCL}, \mathrm{pH} 7.2$ ), the membrane was treated with $30 \mathrm{ml}$ of $10 \mathrm{mM}$ Na periodate* , $100 \mathrm{mM}$ CH3COONa, and 5mM EDTA for $20 \mathrm{mn}$ in the dark. The membrane was then washed three times 10min each with PBS buffer before adding $30 \mathrm{ml}$ of a mixture containing $6 \mu$ l hydrazide, $30 \mathrm{ml}$ CH3COONa $100 \mathrm{mM}$, and 5mM EDTA. The membrane was then washed three times $10 \mathrm{mn}$ with $30 \mathrm{ml}$ of TBS (50 mM Tris, $27 \mathrm{mM} \mathrm{NaCl}, \mathrm{pH} 7.2$ ) under stirring. In order to block the non-specific sites, $0.25 \mathrm{~g}$ of gelatin in $50 \mathrm{ml}$ TBS was added during one night at $4{ }^{\circ} \mathrm{C}$ without stirring. After new washings (3 times $10 \mathrm{mn}$ ) with TBS the complex was revealed by $30 \mathrm{ml}$ of TBS containing 150 $\mu \mathrm{l}$ of NTB (nitroblue tetrazolium) and $112.5 \mu \mathrm{l}$ of BCIP (bromochloroindolyl phosphate). The staining was stopped with distilled water.

* The concentration of the solution was $0.1 \mathrm{~g} / \mathrm{l}$ for the sialic acid oxidation $(0.16 \mathrm{mM})$. 


\section{Protein digestion and mass spectrometry}

Following electrophoresis and Coomassie blue staining, the $65-\mathrm{kDa}$ band was excised from the gel and was washed twice with water and twice with $100 \mathrm{mM}$ sodium hydrogen carbonate $\left(\mathrm{NaHCO}_{3}\right)$ and $50 \%$ acetonitrile before complete dehydration by vacuum centrifugation. Gel pieces were rehydrated with trypsin solution $(10 \mathrm{~L}$ of $15 \mathrm{ng} / \mathrm{l}$ sequencing-grade trypsin [Boehringer-Manheim, Manheim, Germany] in $100 \mathrm{mM} \mathrm{NaHCO} 3,5 \mathrm{mM} \mathrm{CaCl}_{2}$ ). Tryptic digestion was carried out overnight at $25{ }^{\circ} \mathrm{C}$. The tryptic digest was extracted successively with a $100 \%$ acetonitrile, $100 \mathrm{mM} \mathrm{NaHCO}_{3}$ solution and 5\% formic acid. The digest solution and the extracts were pooled and dried in a vacuum centrifuge before nanospray MS/MS analysis. A QSTAR-Pulsar-i instrument (Applied Biosystems, Foster City, USA) was used with a Z-Spray ion source working in the nanospray mode. Amino acid sequences were analysed with Protein Prospector (http://prospector.ucsf.edu). These sequences were used for BLAST and FASTA homology searches. This experiment was repeated with endoproteinase Asp N (Boehringer-Manheim, Manheim, Germany), V8 protease (Roche Applied Science, Basel, Switzerland) and with cyanogen bromide instead of trypsin. The conditions were identical except that the incubation temperature was $37{ }^{\circ} \mathrm{C}$ and the solution of $\mathrm{NaHCO}_{3}$ did not contain $\mathrm{CaCl}_{2}$. Moreover, the incubation period was reduced to $1 \mathrm{~h}$ for digestion by V8 protease. Some of the peptides were separated by high-performance liquid chromatography and the N-terminal amino acid sequence was determined by automated Edman degradation with the Procise 494A protein sequencing system (Applied Biosystems, Foster City, USA)

\section{Isolation and sequencing of the tr65 gene}

Total mRNA was extracted from rainbow trout skin (Mirwart strain from Pisciculture Expérimentale du Drennec, Sizun, France) with TRIzol (Gibco BRL) according to the manufacturer's instructions and cDNA was synthesised using the Universal RiboClone cDNA synthesis system (Promega, Madison, Wisconsin, USA). The degenerated primers 5'GCTGCAGCCATGAGCATC-3' and 5'-TGTCACAGCACTGTCAACCA-3' designed from the corresponding peptide sequences were used for PCR amplification using cDNA template. The PCR products were then ligated directly into the pCR2.1 plasmid (Invitrogen, Carlsbad, California). E. coli One Shot Cells (Invitrogen, Carlsbad, California) were transformed and grown overnight on LB plate supplemented with ampicillin. Colonies containing the recombinant plasmid were grown overnight in LB-ampicillin broth and the plasmid DNA was 
isolated with a Qiagen plasmid purification kit and stored at $-20^{\circ} \mathrm{C}$. The cloned PCR products were verified by DNA sequencing (Cybergene, Evry, France).

\section{Bacterial strains and growth conditions}

Strains used for cloning and production of recombinant proteins were E. coli DH5 $\alpha$ (Clontech Laboratories, Inc., Palo Alto, Calif.) and E. coli BL21(DE3)omp8, a universal expression host lacking genes for the major E. coli outer membrane proteins LamB, OmpA, OmpC, and OmpF [24]. E. coli strains were maintained and grown in LB medium at $37{ }^{\circ} \mathrm{C}$. When required, the media were supplemented with $100 \mu \mathrm{g} / \mathrm{ml}$ ampicillin and/or $50 \mu \mathrm{g} / \mathrm{ml}$ kanamycin.

\section{Amplification and cloning of tr65}

The 1740-bp full-length tr65 gene, with appropriate sites at both ends, was synthesised by PCR amplification of genomic DNA with primer \#245, 5'TATGGATCCATGAGCATCAGTTACAAGAGCAG-3' (containing a BamHI site indicated in bold and an initiation codon indicated by underlining), and primer \#246, 5'TATAAGCTTTTAGAAGCGTCTGGATGTGGAGG-3’' (containing a HindIII site indicated in bold, and a stop codon indicated by underlining). The PCR products were digested with BamHI and HindIII and ligated into the PETSIG vector prepared by previous digestion with the same enzymes, yielding pETSIG-tr65. The pETSIG vector is a pET28a (Novagen, Wisconsin, USA) derivative that enables production of the His-tagged protein of interest as an $\mathrm{N}$-terminal fusion product with the signal peptide of $E$. coli OmpA porin, allowing targeting of the proteins to the outer membrane [25].

\section{Production and Purification of recombinant Tr65}

E. coli BL21(DE3)omp8 cells were transformed with pETSIG-tr65. The recombinant strains were selected on LB agar supplemented with ampicillin and kanamycin. Liquid cultures were incubated at $37{ }^{\circ} \mathrm{C}$ with shaking until $A_{600}$ reached 0.5 . IPTG was added at a final concentration of $0.5 \mathrm{mM}$ and the incubation continued for an additional $4 \mathrm{~h}$ at $37{ }^{\circ} \mathrm{C}$ with shaking. Cells were harvested by centrifugation for $10 \mathrm{~min}$ at $6,000 \mathrm{~g}$ and resuspended in lysis buffer (50 mM Tris-HCl, pH 8, 300 mM NaCl, 10\% glycerol, 1 mM mercaptoethanol, antiprotease cocktail, Roche Applied Science, Basel, Switzerland). Cells were then disrupted by sonication and the resulting suspension was centrifuged for $1 \mathrm{~h}$ at 55,000 $\mathrm{g}$ at $4{ }^{\circ} \mathrm{C}$. 
The membrane pellet was resuspended and incubated at room temperature for $2 \mathrm{~h}$ in buffer (50 mM Tris-HCl, pH 8, $300 \mathrm{mM} \mathrm{NaCl}, 3 \%$ OPOE [n-octyl-polyoxyethylene]). The final suspension was centrifuged for $1 \mathrm{~h}$ at 55,000 $\mathrm{g}$ at $4{ }^{\circ} \mathrm{C}$. A second step of purification included resuspension of the pellet which was then incubated for $2 \mathrm{~h}$ at room temperature in buffer (50 $\mathrm{mM}$ Tris-HCl, $\mathrm{pH}$ 8, $300 \mathrm{mM} \mathrm{NaCl}, 6 \mathrm{M}$ urea). The final suspension was centrifuged for $1 \mathrm{~h}$ at $55,000 \mathrm{~g}$ at $4{ }^{\circ} \mathrm{C}$. The supernatants were incubated with Ni-NTA agarose suspension (Qiagen, Hilden, Germany). The protein-resin complex was packed into a column and washed extensively with buffer consisting of $50 \mathrm{mM}$ Tris- $\mathrm{HCl} \mathrm{pH}$ 8, $300 \mathrm{mM} \mathrm{NaCl}, 2 \mathrm{M}$ urea and 15 $\mathrm{mM}$ imidazole. The proteins were eluted with buffer consisting of $50 \mathrm{mM}$ Tris- $\mathrm{HCl} \mathrm{pH} 8,300$ $\mathrm{mM} \mathrm{NaCl}, 1 \mathrm{M}$ urea and $300 \mathrm{mM}$ imidazole. The eluted fractions were analysed by SDSPAGE. Recombinant Tr65 with the hexahistidine(His 6 )-tag removed was produced by the same protocol with the final step modified as follows. The protein-resin complex was treated overnight with protease (Amersham) to cleave the thrombin-recognition sequence of the linker fusing the tag to the recombinant Tr65. The protein was eluted with $50 \mathrm{mM}$ Tris- $\mathrm{HCl}$, $\mathrm{pH}$ 8, $300 \mathrm{mM} \mathrm{NaCl}, 1 \mathrm{M}$ urea. Protein concentrations were determined by measuring the absorbance at $280 \mathrm{~nm}$ before the addition of the anti-protease cocktail (Roche Applied Science, Basel, Switzerland).

\section{Conductance experiments}

We used the Montal and Mueller technique [26] to form virtually solvent-free planar lipid bilayers for macroscopic and single-channel conductance experiments. The membranes were formed over a 100 to $150 \mu \mathrm{m}$ hole in Teflon film (10 $\mu \mathrm{m}$ thick) and pre-treated with a 1:40 mixture (v/v) of hexadecane/hexane, separating two half cells. Lipid monolayers from a 5 $\mathrm{mg} / \mathrm{ml}$ azolectin solution (Soybean azolectin IV-S, Sigma) were spread on top of an electrolyte solution ( $1 \mathrm{M} \mathrm{KCl,} 10 \mathrm{mM}$ HEPES $\mathrm{pH}$ 7.4) in each of the two compartments. Bilayers were formed by lowering and raising the level of electrolyte in one side or both sides. A voltage was applied by an $\mathrm{Ag} / \mathrm{AgCl}$ electrode on the cis-side. For the macroscopic conductance experiments, the doped membranes were subjected to slow voltage ramps (10 $\mathrm{mV} / \mathrm{s}$ ) and the transmembrane currents were amplified (BBA-01, Eastern Scientific, Rockville, USA). The current-voltage curves were stored on a computer and analysed with Scope software (Bio-Logic, Claix, France). For single-channel recording, the potentials were applied and the currents amplified simultaneously with an amplifier (BLM 120, Bio-Logic). Single-channel currents were stored on a compact disc (CD) (DRA 200, Bio-Logic) for offline analysis. Windac32 (http://www.shareit.com) and Biotools (Bio-Logic) software were 
used to analyse the CD data. All experiments were carried out at room temperature. Data were filtered at $1 \mathrm{kHz}$ before digitizing at $11.2 \mathrm{kHz}$ for analysis. In both cases, the proteins were incubated in 1\% OPOE or in dodecylmaltoside (DDM) in different dilutions before incorporation into the membrane.

\section{RESULTS}

We have previously [21] isolated the antibacterial protein Tr65 from trout mucus and established a good correlation between its antimicrobial activity and pore-forming properties. Unfortunately, the amounts of recovered protein were too small for determining its structure. This study aimed to determine the gene sequence of this protein, enabling the construction of a recombinant $\operatorname{Tr} 65$ that can be overproduced in $E$. coli.

\section{Extraction, Purification and Characterisation of the native Tr65 protein}

We carried out a differential extraction from lyophilised mucus by lithium dodecyl sufate (LiDS) (see ref [21]). The protein Tr65 was isolated from supernatant by preparative LiDSPAGE followed by electroelution. We obtained only one band (Fig. 1A), indicating high purity of Tr65. Nevertheless, we conducted 2D electrophoresis i) to control the integrity of the protein and ii) to detect the presence of isomorphic proteins. We observed four spots with the same molecular mass on the $2 \mathrm{D}$ gel (Fig. 1B) at pH 3.3, 3.5, 5.1 and 5.2. These findings seem to indicate that Tr65 has various functional groups. As numerous proteins in the trout mucus are glycosilated, we performed experiments in order to determine the presence of carbohydrates in Tr65. The carbohydrate groups were specifically oxidized then labelled with biotin before treatment with streptavidine-alkalin phosphatase. The coloration was made with NBT-BCIP (nitroblue tetrazolium-Bromochloroindolyl phosphate). The purity control of the Tr65 protein is shown in Fig. 1C left panel while the Fig1C right panel shows unambiguously the presence of carbohydrates (lane 2) and sialic acids (lane 3).

We conducted an antibacterial test and reconstitution experiments in planar lipid bilayers in order to determine the functionality of Tr65. We observed the same minimal inhibitory concentration as in our previous study (data not shown, see ref [21]). Though we could not determine unitary conductance for Tr65 in our preliminary study, we obtained here well defined single channels in azolectin bilayers. The trace on the figure 2 shows a 515 pS level due to simultaneous insertions of Tr65 and fluctuations of $35 \mathrm{pS}$ corresponding to unitary conductances of Tr65 channels in $1 \mathrm{M} \mathrm{NaCl}$. A same behaviour was observed in $1 \mathrm{M} \mathrm{KCl}$ but the conductance values were $40 \mathrm{pS}$. 


\section{Determination of the tr65 gene sequence}

Sequencing of native Tr65 by Edman degradation was unsuccessful, probably due to Nterminal protection. We obtained proteolytic fragments of native Tr65 by enzymatic digestion with trypsin, V8 protease and endoproteinase Asp $\mathrm{N}$ and by chemical degradation with $\mathrm{CNBr}$. These fragments were sequenced by Edman degradation and analysed by mass spectroscopy (Table 1). Similarity searches in data banks (Pattin Prot) identified a very high degree of similarity with a cytokeratin of rainbow trout (accession number Q90W76). Eleven of 18 proteolytic fragments were $100 \%$ identical and six of 18 were about $90 \%$ identical with the sequence of this keratin. We synthesised primers based on these sequences. We constructed a cDNA library from RNA extracted from trout skin. We used PCR at various hybridisation temperatures with appropriate primers to generate several tr65 clones. Sequence analysis showed that only one matched all sequences described in Table 1 . The protein translated from this cloned gene is very similar to the keratin Q90W76 (Fig. 3). However, residues from 105 to 140 of the keratin Q90W76 are absent in the Tr65 sequence. Keratin Q90W76 has a molecular mass of 62,344 Da for its 618 residues and Tr65 has a molecular mass of 59,574 Da for its 579 residues. The amino acid composition shows a strong proportion of serine and glycine residues (11.4 and $22.3 \%$ respectively).

\section{Extraction, Purification and Characterisation of recombinant Tr65}

The amounts of Tr65 extracted from the mucus of trout were too low to conduct structural studies. Thus, we attempted to produce a recombinant Tr65 in various strains of E. coli.

We used E. coli BL21(DE3)omp8 to produce His 6 -Tr65. This strain is devoid of many porins [24] and is thus an ideal tool for the production and subsequent characterisation of proteins with pore-forming activities, as contamination with endogenous porins is not possible. However, our attempt to produce $\mathrm{His}_{6}$-Tr65 by transformation of E. coli BL21(DE3)omp8 with pET28a-tr65 was unsuccessful, probably due to toxicity of the eukaryotic Tr65 (data not shown). We also tried to produce glutathione GST-tagged Tr65 with a pGEX(M) [27] vector. However, GST-Tr65 was only present in insoluble fractions (data not shown). Furthermore, high concentrations of urea are required to solubilise the target protein and thus glutathione beads cannot be used. We then tested another vector for significant expression. The pETSIG vector is derived from pET28a, as described previously [25]. This vector allows the His 6 -tagged protein to be produced as an N-terminal fusion product with the signal peptide of E. coli OmpA porin, targeting the protein to the outer 
membrane. Introduction of this vector into E. coli BL21(DE3)omp8 led to production of a satisfactory amount of the fusion protein, though most recombinant Tr65 was found in inclusion bodies (data not shown). Some recombinant Tr65 was correctly targeted to the membrane fraction. We tried to extract this fraction using 3\% octyl-polyoxyethylene (OPOE), a mild detergent compatible with later purification steps and conductance experiments. However, this extraction did not recover the recombinant protein; neither did Empigen, a detergent known to solubilise keratins [28]. We succeeded in recovering the fusion protein from membrane extract with $2 \%$ SDS. Unfortunately, SDS appears to be incompatible with further purification with Ni-NTA beads and with biophysical analysis of pore-forming properties. Thus, we focused on the fusion protein accumulated in insoluble inclusion bodies and we finally chose the $\mathrm{His}_{6}$-Tr65 construct including the E. coli OmpA signal peptide to produce recombinant Tr65 because Ni-NTA beads used for purification are compatible with high concentrations of denaturant. We then extracted recombinant Tr65 from the inclusion bodies with $6 \mathrm{M}$ urea. This fusion protein precipitated after traditional dialysis to remove the denaturant. Therefore, we used Ni-NTA resin to immobilise recombinant Tr65 while it was refolded by gradually decreasing the concentration of denaturant (final concentration $1 \mathrm{M}$ ). We then eluted recombinant Tr65 with a buffer containing $300 \mathrm{mM}$ imidazole. We also produced recombinant Tr65 from which the His-tag was removed by thrombin cleavage while the refolded recombinant Tr65 was still bound to the Ni-NTA resin. The tag was cleaved successfully at overnight incubation at room temperature. SDS-PAGE analysis of both proteins (Fig. 4) showed that we obtained His $_{6}$-Tr65 and Tr65 with a high purity.

\section{Pore-forming properties}

We incorporated Tr65 (after dilution in 1\% OPOE) into azolectin planar lipid bilayers formed by the Montal-Mueller technique[26]. Typically, after allowing the membrane to stabilise (30 $\mathrm{min})$, we subjected the bilayers to repetitive triangular ramps $(10 \mathrm{mV} / \mathrm{s})$. Fig. 5 shows currentvoltage (I-V) curves recorded in $1 \mathrm{M} \mathrm{KCl}$ electrolyte solution according to progressive incorporation of Tr65 in the membrane. The various I-V curves show ohmic behaviour, indicating non-voltage dependence for Tr65, i.e. the formation of channels is independent of the applied voltage. This behaviour is similar to that of porins of the outer membrane of gramnegative bacteria. These porins induce the opening of water-filled channels independent of voltage. We carried out single-channel experiments with purified His ${ }_{6}$-Tr65 and Tr65 inserted into planar lipid bilayers. Under an applied voltage, both these proteins induced well defined fluctuations of current. (Fig. 6). We observed conductance values of $180 \pm 15$ pS for Tr65 and 
$210 \pm 20$ pS for His 6 -Tr65 in $1 \mathrm{M} \mathrm{KCl}$. We occasionally observed a conductance value of 220 pS for Tr65. Theses findings suggest that the presence of the His-tag does not significantly modify the behaviour of $\mathrm{His}_{6}$-Tr65. We tested also both proteins at increasing dilutions in OPOE or in DDM in order to improve the refolding of Tr65. Whatever the nature and the dilution of the detergent may be, we did not observe modifications of the conductance values.

\section{DISCUSSION}

It is well established that mucus, along with having other important biological functions, contributes to the defence system of fish. Previously, we showed that several glycoproteins isolated from hydrophobic supernatants of epidermal mucus of fresh water fish and salt water fish have pore-forming properties that correlated well with strong antibacterial activity [21, 22]. In this paper, we focused on the trout glycoprotein Tr65 to determine its primary amino acid sequence and to produce a recombinant protein for future structural studies.

N-terminal sequencing of this protein was unsuccessful, as observed for other glycoproteins extracted from tench, carp, eel and turbot (unpublished data), suggesting that the N-terminal part of these proteins is protected. Proteolytic fragments from Tr65 were obtained by digesting the protein with various enzymes and chemical degradation reactions. We determined the sequences of these fragments by Edman degradation and by mass spectroscopy (Table 1). We found a very high degree of similarity between these internal sequences and the trout Oncorhynchus mykiss type II epidermal keratin E1 (SwissProt accession number Q90W76). Major functions of this subfamily of keratins involve epidermis architecture and regulation of epidermal cell development [29]. This type of structural protein has already been observed in the mucus of other teleost fish, including Atlantic salmon (Salmo salar) [30] and discus fish (Symphysodon spp.) [31]. Keratin protein content is higher in parental mucus of discus fish (Symphysodon spp.) than in mucus from juveniles. This difference may be due to various factors, including the stressfull condition of losing epidermal layers of mucus during larval feeding activities [27]. Type II homologues of epidermal keratin have also been detected in the external mucus of Pacific hagfish (Eptatretrus stouti, class Myxini) [32], a primitive jawless vertebrate of ancient linage that can produce voluminous quantities of mucus when stressed.

We synthesised various primers and constructed a cDNA library to determine the complete amino acid sequence of Tr65 by gene sequencing. We generated and sequenced 
clones of PCR products from reactions carried out at various hybridisation temperatures. Only one matched with all sequences described in Table 1. The protein sequence translated from this gene confirms the very strong similarity previously observed with a trout keratin (subtype $\mathrm{II}_{\mathrm{E}}$ ) expressed in epidermal keratinocytes (SwissProt accession number: Q90W76), except for the absence of the area corresponding to residues 105 to 140 of the trout keratin (Fig. 3).

We chose to produce recombinant Tr65 in E. coli because the amounts of Tr65 extracted from the mucus of trout were too small to conduct structural studies. It appears that recombinant protein was also necessary to confirm the pore-forming properties observed with the native Tr65 isolated from mucus, as this property has not been described previously for keratins. This control would definitively exclude the possibility that the ion channels observed in planar lipid bilayers were due to the putative presence of contaminant proteins.

We tested several plasmids to identify one that would adequately produce recombinant Tr65. Finally, we chose the pETSIG vector, derived from pET28a as described previously [25]. With this vector, the His $_{6}$-tagged protein was produced mainly in inclusion bodies. We extracted the recombinant protein from the inclusion bodies with $6 \mathrm{M}$ urea and immobilized the protein on a column of Ni-NTA resin. Gradually decreasing the concentration of denaturant allowed the recombinant protein to refold. We recovered His $6^{-}$Tr65 by elution with imidazole and Tr65 after cleavage by thrombin. We carried out multi-channel experiments with both these proteins and observed the same behaviour as that of native Tr65, i.e. ohmic I/V curves indicating voltage-independent behaviour.

Single-channel experiments with both recombinant proteins gave similar values of conductance around $200 \mathrm{pS}$ in $1 \mathrm{M} \mathrm{KCl}$. These results indicate that the presence of the His 6 tag does not influence the pore-forming properties of His 6 -Tr65. However, these conductance values were greater than that for native Tr65 (40 pS). Additional refolding experiments did not display modifications of conductance value of $\operatorname{Tr} 65(180 \mathrm{pS})$. This difference may be explained by a slight structural difference due to refolding of the recombinant Tr65 and to the presence of post-translational modifications in the native Tr65. This later hypothesis was confirmed by the detection of carbohydrate groups in the native Tr65 (Fig. 1C). Moreover native Tr65 probably has various levels of phosphorylation, as we observed several spots at various pIs by $2 \mathrm{D}$ electrophoresis. Finally sequencing of native Tr65 by Edman degradation was unsuccessful due to $\mathrm{N}$-terminal protection. All these post-translational modifications must also be important for folding of the native Tr65, as $6 \mathrm{M}$ urea is not required to solubilise native Tr65, but is required to solubilise recombinant Tr65. These slight structural differences between the native and recombinant Tr65 would be responsible for the modification of pore- 
forming properties. Numerous studies showed that the dephosphorylation or deglycosylation of membrane proteins can conduct to dramatic changes in their channel properties [33-36]. Nevertheless, this study clearly shows for the first time that a protein from the keratin family has pore-forming properties in an artificial membrane.

Our findings suggest that type II epidermal keratins in the mucus of fish could contribute to host defence against water-borne microorganisms. Indeed, Atlantic salmon have been shown to have a higher epidermal keratin content in the mucus after being exposed to sea lice (Lepeophtheirus salmonis) [30]. Additionally, cytokeratins (or fragments of cytokeratins) are consistently found at higher levels after infection of the mucosal surfaces of mammals [37, 38]. For example, a $5.7 \mathrm{kDa}$ peptide with similarity to the tail of human cytokeratin 7 has been found in the bladder mucosal surface of pig. This peptide, PiBP-5, is clearly involved in the defence mechanisms of the urinary bladder against bacterial infections [37]. PiBP-5 has a high content of glycine (20.0\%) and serine (16.3\%) residues, as does Tr65 (22.3\% glycine and $11.4 \%$ serine). Substantial transcriptional changes for keratin genes have also been observed in the human airway epithelium in response to infection by Pseudomonas aeruginosa [38]. The human airway epithelium is continuously exposed to potentially harmful microorganisms, as is the epidermal surface of fish, and plays a central role in innate immunity. The authors proposed that increased expression of keratin genes after exposure to P. aeruginosa plays a crucial role in maintaining the physical epithelial barrier. Though it now appears that teleost $\mathrm{II}_{\mathrm{E}}$ keratins diversified independent of mammalian $\mathrm{II}_{\mathrm{E}}$ keratins [39], it would be interesting to investigate whether mammalian cytokeratins have similar poreforming and antibacterial properties. Perhaps the differential expression of keratin genes in human airway epithelium in response to $P$. aeruginosa is due to a direct contribution of cytokeratins to innate immunity. 


\section{REFERENCES}

1 Ellis, A. E. (1999) Immunity to bacteria in fish Fish Shellfish Immunol. 9, 291-308

2 Ellis-AE (2001) Innate host defense mechanisms of fish against viruses and bacteria. Developmental And Comparative Immunology. Oct Dec 25, 827-839

3 Magnadottir, B. (2006) Innate immunity of fish (overview). Fish Shellfish Immunol.. 20, $137-151$

4 Alexander, J. B. and G.A, I. (1992).Non-cellular non-specific defense mechanisms of fish. Ann. Rev. Fish Dis 2, 249-279

5 Kaattari, S. L. and Piganelli, J. D. (1996) The specific immune system: humoral defense

In The Fish Immune System: Organism, Pathogen and Environment. Fish Physiology (Iwama, G. N., T., ed.), pp. 207-254., Academic Press, San Diego

6 Tatner, M. F. (1986) The ontogeny of humoral immunity in rainbow trout, Salmo gairdneri. Vet Immunol Immunopathol 12, 93-105

7 Le Morvan, C., Deschaux, P. and Troutaud, D. (1996) Effects and mechanisms of environmental temperature on carp (Cyprinus carpio) anti-DNP antibody response and non-specific cytotoxic cell activity: a kinetic study. Dev Comp Immunol 20, 331-340

8 Le Morvan, C., Troutaud, D. and Deschaux, P. (1998) Differential effects of temperature on specific and nonspecific immune defences in fish. J. Exp. Biol. 201, 165-168

9 Russell, S. L., J.S. (2005) Function and heterogeneity of fish lectins. Vet. Immunol. Immunopathol. 108, 111-120.

10 Yano, T. (1996) The nonspecific immune system: humoral defense In The fish immune system: organism pathogen and environment (Iwama, G. and Nakanishi, T., eds.), pp. 105-157, Academic Press, San Diego, CA

11 Adermann, K., Raida, M., Paul, Y., Abu-Raya, S., Bloch-Shilderman, E., Lazarovici, P., Hochman, J. and Wellhoner, H. (1998) Isolation, characterization and synthesis of a novel paradaxin isoform. FEBS Lett 435, 173-177

12 Lazarovici, P., Primor, N. and Loew, L. M. (1986) Purification and pore-forming activity of two hydrophobic polypeptides from the secretion of the Red Sea Moses sole (Pardachirus marmoratus). J. Biol. Chem. 261, 16704-16713 
13 Cole, A. M., Weis, P. and Diamond, G. (1997) Isolation and characterization of pleurocidin, an antimicrobial peptide in the skin secretions of winter flounder. $\mathrm{J}$ Biol Chem 272, 12008-12013

14 Shiomi, K., Igarashi, T., Yokota, H., Nagashima, Y. and Ishida, M. (2000) Isolation and structures of grammistins, peptide toxins from the skin secretion of the soapfish Grammistes sexlineatus. Toxicon 38, 91-103

15 Shiomi, K., Yokota, H., Nagashima, Y. and Ishida, M. (2001) Primary and secondary structures of grammistins, peptide toxins isolated from the skin secretion of the soapfish pogonoperca punctata. Fisheries Science. 67, 163-169.

16 Sugiyama, N., Araki, M., Ishida, M., Nagashima, Y. and Shiomi, K. (2005) Further isolation and characterization of grammistins from the skin secretion of the soapfish Grammistes sexlineatus. Toxicon 45, 595-601

17 Park, I. Y., Park, C. B., Kim, M. S. and Kim, S. C. (1998) Parasin I, an antimicrobial peptide derived from histone H2A in the catfish, Parasilurus asotus. FEBS Lett. 437, 258-262

18 Fernandes, J. M., Kemp, G. D., Molle, M. G. and Smith, V. J. (2002) Anti-microbial properties of histone H2A from skin secretions of rainbow trout, Oncorhynchus mykiss. Biochem. J. 368, 611-620

19 Fernandes, J. M., Molle, G., Kemp, G. D. and Smith, V. J. (2004) Isolation and characterisation of oncorhyncin II, a histone H1-derived antimicrobial peptide from skin secretions of rainbow trout, Oncorhynchus mykiss. Dev. Comp. Immunol. 28, $127-138$

20 Birkemo, G. A., Luders, T., Andersen, O., Nes, I. F. and Nissen-Meyer, J. (2003) Hipposin, a histone-derived antimicrobial peptide in Atlantic halibut (Hippoglossus hippoglossus L.). Biochim. Biophys. Acta 1646, 207-215

21 Ebran, N., Julien, S., Orange, N., Auperin, B. and Molle, G. (2000) Isolation and characterization of novel glycoproteins from fish epidermal mucus: correlation between their pore-forming properties and their antibacterial activities. Biochim Biophys Acta 1467, 271-280.

22 Ebran, N., Julien, S., Orange, N., Saglio, P., Lemaitre, C. and Molle, G. (1999) Poreforming properties and antibacterial activity of proteins extracted from epidermal mucus of fish. Comp Biochem Physiol A Mol Integr Physiol 122, 181-189.

23 Vilain, S., Cosette, P., Charlionet, R., Hubert, M., Lange, C., Junter, G. A. and Jouenne, T. (2001) Substituting Coomassie Brilliant Blue for bromophenol blue in 
two-dimensional electrophoresis buffers improves the resolution of focusing patterns. Electrophoresis 22, 4368-4374

24 Prilipov, A., Phale, P. S., Van Gelder, P., Rosenbusch, J. P. and Koebnik, R. (1998) Coupling site-directed mutagenesis with high-level expression: large scale production of mutant porins from E. coli. FEMS Microbiol. Lett. 163, 65-72.

25 Siroy, A., Molle, V., Lemaitre-Guillier, C., Vallenet, D., Pestel-Caron, M., Cozzone, A. J., Jouenne, T. and De, E. (2005) Channel formation by CarO, the carbapenem resistance-associated outer membrane protein of Acinetobacter baumannii. Antimicrob Agents Chemother 49, 4876-4883

26 Montal, M. and Mueller, P. (1972) Formation of bimolecular membranes from lipid monolayers and a study of their electrical properties. Proc. Natl. Acad. Sci. U S A 69, 3561-3566.

27 Molle, V., Brown, A. K., Besra, G. S., Cozzone, A. J. and Kremer, L. (2006) The condensing activities of the Mycobacterium tuberculosis type II fatty acid synthase are differentially regulated by phosphorylation. J Biol Chem 281, 30094-30103

28 Lowthert, L. A., Ku, N. O., Liao, J., Coulombe, P. A. and Omary, M. B. (1995) Empigen BB: a useful detergent for solubilization and biochemical analysis of keratins. Biochem. Biophys. Res. Commun. 206, 370-379

29 Conrad, M., Lemb, K., Schubert, T. and Markl, J. (1998) Biochemical identification and tissue-specific expression patterns of keratins in the zebrafish Danio rerio. Cell Tissue Res 293, 195-205

30 Easy, R. H. and Ross, N. W. (2006) Proteomic analysis of the epidermal mucus of Atlantic salmon (salmon salar): Biological indicators of stress. In 7th International Congress on the Biology of Fish. (Mac Kinlay, C. and Busby, C., eds.), pp. 90, St Johnn's, Newfoundland, Canada.

31 Chong, K., Ying, T. S., Foo, J., Jin, L. T. and Chong, A. (2005) Characterisation of proteins in epidermal mucus of discus fish (Symphosodon spp.) during parental phase Aquaculture 249, 469-476

32 Koch, E. A., Spitzer, R. H., Pithawalla, R. B., Castillos, F. A., 3rd and Parry, D. A. (1995) Hagfish biopolymer: a type I/type II homologue of epidermal keratin intermediate filaments. Int J Biol Macromol 17, 283-292

33 Weiger, T. M., Hermann, A. and Levitan, I. B. (2002) Modulation of calciumactivated potassium channels. J. Comp. Physiol. A Neuroethol. Sens Neural Behav. Physiol. 188, 79-87 
34 Sivilotti, L. G., McNeil, D. K., Lewis, T. M., Nassar, M. A., Schoepfer, R. and Colquhoun, D. (1997) Recombinant nicotinic receptors, expressed in Xenopus oocytes, do not resemble native rat sympathetic ganglion receptors in single-channel behaviour. J. Physiol. 500 ( Pt 1), 123-138

35 Moreno, A. P. and Lau, A. F. (2007) Gap junction channel gating modulated through protein phosphorylation. Prog. Biophys. Mol. Biol. 94, 107-119

36 Schmieder, S., Bogliolo, S. and Ehrenfeld, J. (2007) N-glycosylation of the Xenopus laevis ClC-5 protein plays a role in cell surface expression, affecting transport activity at the plasma membrane. J. Cell Physiol. 210, 479-488

37 Qi, W. and Boyao, W. (1999) Defense mechanisms of urinary bladder: studies on antimicrobial polypeptides from bladder mucosa. Chin. Med. Sci. J. 14, 17-22

38 Vos, J. B., van Sterkenburg, M. A., Rabe, K. F., Schalkwijk, J., Hiemstra, P. S. and Datson, N. A. (2005) Transcriptional response of bronchial epithelial cells to Pseudomonas aeruginosa: Identification of early mediators of host defense. Physiol. genomics 21, 324-336

39 Schaffeld, M., Haberkamp, M., Braziulis, E., Lieb, B. and Markl, J. (2002) Type II keratin cDNAs from the rainbow trout: implications for keratin evolution. Differentiation 70, 292-299 


\section{Table 1}

\begin{tabular}{|l|l|l|l|}
\hline \multicolumn{2}{|c|}{ Edman degradation } & \multicolumn{1}{c|}{ Mass spectroscopy } & $\%$ \\
\hline MDNIVAEVRAQYE $^{\mathrm{a}}$ & 91 & VEVEFVLLK $^{\mathrm{C}}$ & 89 \\
\hline MNVKLALDIEIAT $^{\mathrm{a}}$ & 100 & VDSLQDELNFIR $^{\mathrm{c}}$ & 100 \\
\hline MVKDAKLRIKDL $^{\mathrm{a}}$ & 92 & FASFIDKVR $^{\mathrm{c}}$ & 100 \\
\hline FVLLKKDVDGAYMNK $^{\mathrm{b}}$ & 100 & AQYEDLANR $^{\mathrm{c}}$ & 100 \\
\hline EAEERGEMAV $^{\mathrm{b}}$ & 100 & QLDGLSRK $^{\mathrm{c}}$ & 61 \\
\hline ALKDAKLRIKDLE $^{\mathrm{b}}$ & 93 & SFSSFSSSAVN $^{\mathrm{c}}$ & 91 \\
\hline & & DQYMNKVELEAR $^{\mathrm{c}}$ & 82 \\
\hline & & YEAELSELQ $^{\mathrm{c}}$ & 100 \\
\hline & & DSIVAEVR $^{\mathrm{C}}$ & 100 \\
\hline & & WSLLQDQT $^{\mathrm{c}}$ & 100 \\
\hline & & DFKNKYE $^{\mathrm{d}}$ & 100 \\
\hline & & DQTTTRSNL $^{\mathrm{d}}$ & 100 \\
\hline & & & \\
\hline
\end{tabular}

${ }^{\mathrm{a}} \mathrm{CNBr},{ }^{\mathrm{b}} \mathrm{V} 8$ Protease, ${ }^{\mathrm{c}}$ Trypsin, ${ }^{\mathrm{d}}$ Endoproteinase Asp N

\%: Percentage of similarity with Q90W76

Underlined letters indicate residues without similarity 


\section{FIGURE LEGENDS}

Figure 1. 1D and 2D gel electrophoresis and carbohydrate and sialic acid determination of native Tr65 purified from trout mucus. A) Coomassie-blue-stained gel with purified Tr65 (lane 1) B) Silver-stained gel after the second migration. The four arrows indicate the isoelectric points observed after the 2D migration. Each spot was sequenced by Edman degradation. C) Left panel: Coomassie-blue gel stained. Molecular mass markers (lane 1), Purified native Tr65 (lane 2). Right panel: NBT-BCIP stained gel. Biotinylated molecular mass markers (lane 1), Tr65 for carbohydrate detection (lane 2), Tr65 for sialic acid detection (lane 3).

Figure 2. Single-channel recordings in $1 \mathrm{M}$ NaCl for Tr65 extracted from trout mucus and the associated amplitude histogram. The protein concentration was $0.5 \mathrm{ng} / \mathrm{ml}$. The applied voltage was $120 \mathrm{mV}$.

Figure 3. Alignment of Tr65 and Q90W76 sequences. Bold, underlined characters correspond to an amino-acid residue substitution.

Figure 4. Commassie-blue-stained gel of purified recombinant $\mathrm{His}_{6}$-Tr65 and Tr65 produced in E. coli. Lane 1: Tr65; lane 2: His $_{6}$-Tr65. Molecular mass markers for 97, 66, 45, 30 and $20.1 \mathrm{kDa}$ are shown.

Figure 5. Macroscopic current-voltage curves (I-V) for Tr65 at various concentrations in azolectin membranes. $\mathrm{I}-\mathrm{V}$ curves between -200 and $+200 \mathrm{mV}$ at a ramp sweep of $10 \mathrm{mV} / \mathrm{s}$ in $1 \mathrm{M} \mathrm{KCl}$. Protein concentrations were about $0.5 \mathrm{mg} / \mathrm{l}$. Curves 1,2 and 3 represent the successive insertions of Tr65 in the membrane.

Figure 6. Pore-forming properties of His $_{6}$-Tr65 and Tr65 in 1 M KCl. A) $\mathrm{His}_{6}-\mathrm{Tr} 65$ at $+149 \mathrm{mV}$. B) Tr65 at $-90 \mathrm{mV}$. Protein concentration was $0.5 \mathrm{mg} / \mathrm{l}$ for each of these proteins. The channel conductance was calculated as the difference between the closed state and the open state divided by the applied voltage value. 


\section{Figure 1}

A

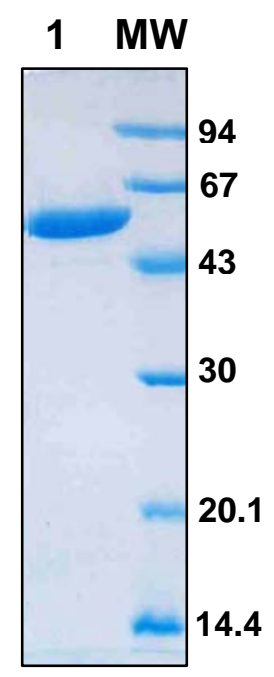

C
B

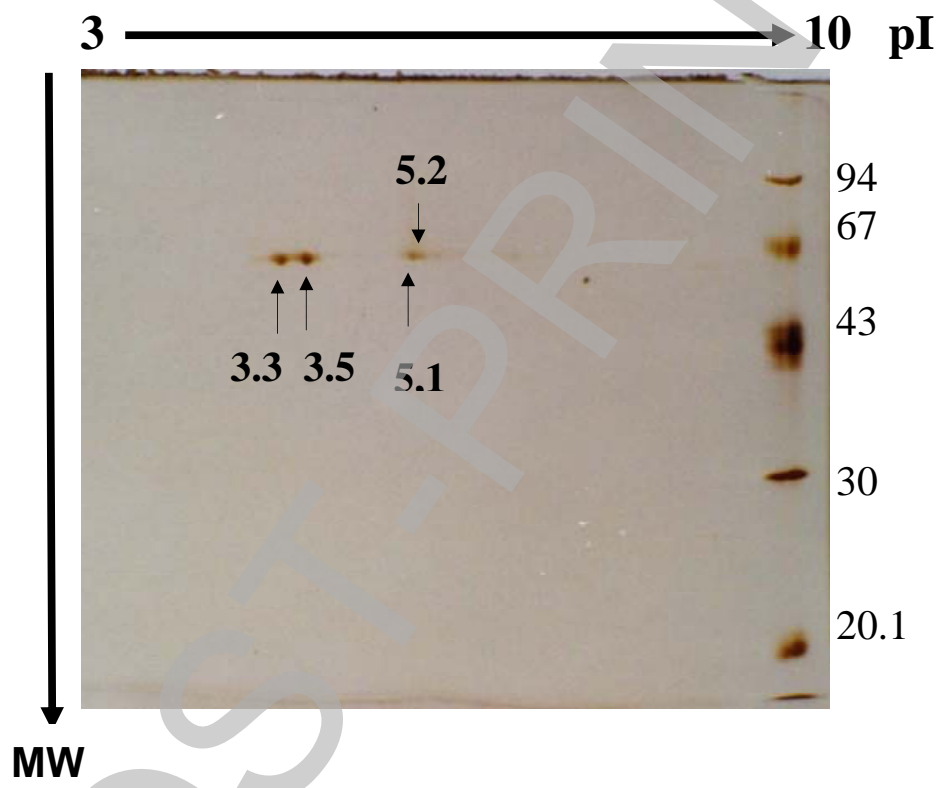

\section{$\begin{array}{lll}1 & 2 & 3\end{array}$}




\section{Figure 2}

A

B

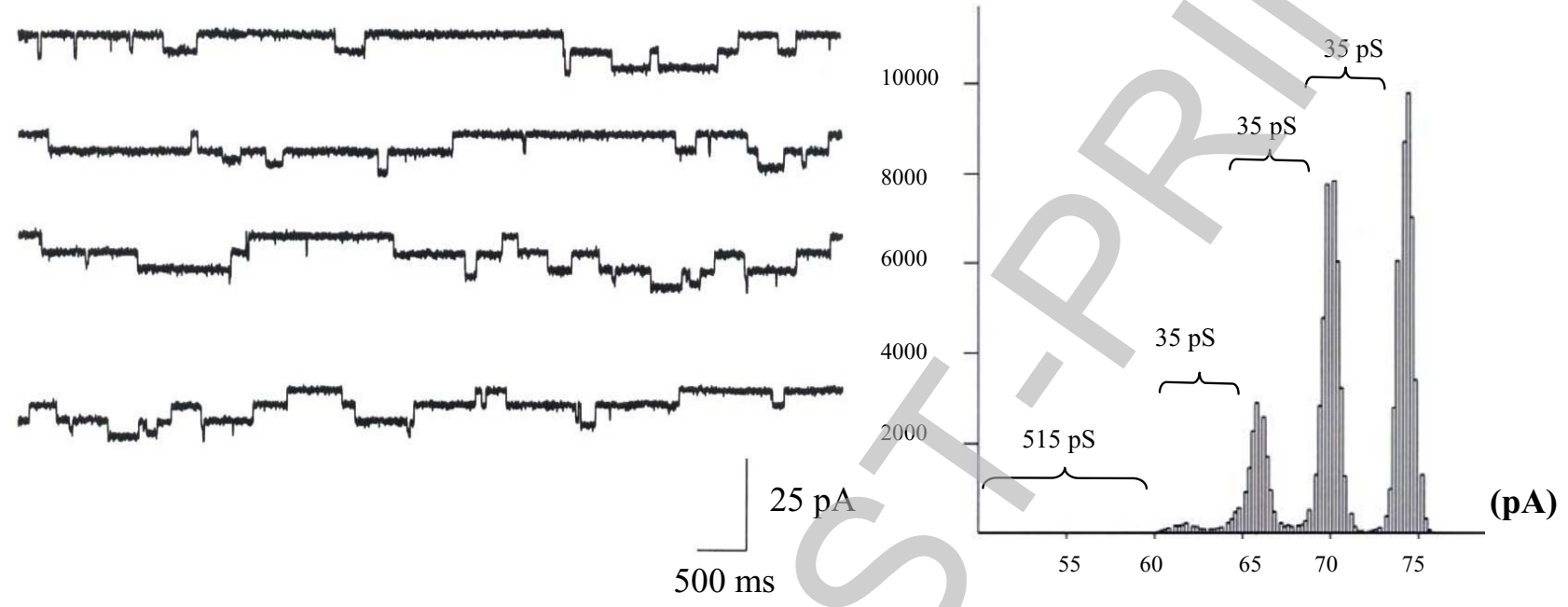




\section{Figure 3}

Tr65
Q90W76
Tr65
Q90W76
Tr65
Q90W76
Tr65
Q90W76
Tr65
Q90W76
Tr65
Q90W76
Tr65
Q90W76
Tr65
Q90W76
Tr65
Q90W76
Tr65
Q90W76
Tr65
Q90W76

1

MSISYKSSGSMSGGFGSSRGFSSGGGGGGGGGSVRKSFSSFSSSAVPMGSSRMSSSSVRR MSISYKSSGSMSGGFGSSRGFSSGGGGGGGGGSVRKSFSSFSSSAVPMGSSRMSS SSVRR SVDGGGGGGFGLGGGGGGG - ISSYSYMSGGGGMGGGGGGGMGGGG - _ _ SVㅁGSGGGGFGLGGGGGGGGISSYSYMSGGGGMGGGGGGGMGGGGFGMGGGGGGFGLGGG - - - - - - - - - - - - - - - - - - GGGFGLGGGGGGFGLGGGGGGFGMGGGGGGFGMGGGGGGGFAPITAVTVNTSLLAPLNLA 240 KWSLLQDQTTTRSNIDAM IDPNIQTVRTQEKEQI KGLNNRFASF IDKVRFLEQQNKMLETKWSLLQDQTTTRSNIDAM

FEAYIANLRRQLDGLGGEKVKLEGELMNMQGLVEDFKNKYEDEINKRASVENEFVLLKKD FEAYIANLRRQLDGLGGEKVKLEGELMNMQGLVEDFKNKYEDEINKRASVENEFVLLKKD

VDGAYMNKVELEARVDSLQDEINFLRAIYEAELSELQGQIKDTSVVVEMDNSRNLDMDSI VDGAYMNKVELEARVDSLQDEINFLRAIYEAELSELQGQIKDTSVVVEMDNSRNLDMDSI

VAEVRAQYEDIANRSRAEAESWYKQKFEEMQSSAGQHGDDLRNTKAEMAELNRMISRLQN VAEVRAQYEDIANRSRAEAESWYKQKFEEMQSSAGQHGDDLRNTKAEMAELNRMISRLQN EIENVKGQRANLENQIAEAEERGEMAVKDAKLRIKDLEEALQRAKQDMARQVREYQELMN EIENVKGQRANLENQIAEAEERGEMAVKDAKLR I KDLEEALQRAKQDMARQVREYQELMN VKLALDIEIATYRKLLEGEESRITGGGTGGGIATIHVQTSSSGGGGG - - SGGGFGMGGGG VKLALDIEIATYRKLLEGEESRITGGGTGGGIATIHVQTSSSGGGGGGGSGGGFGMGGGG GGGG - FGYGGGS SMSMKS SGGFGMS SGGGGGGGFGMSGGGGGGFGMSGGGGGGSGFGMSG GGGGGFGYGGGSSMSMKSSGGFGMSSGGGGGGGFGMSGGGGGGFGMSGGGGG - SGFGMSG

GGGGVSMSRSSMTSTSRRF 


\section{Figure 4}




\section{Figure 5}

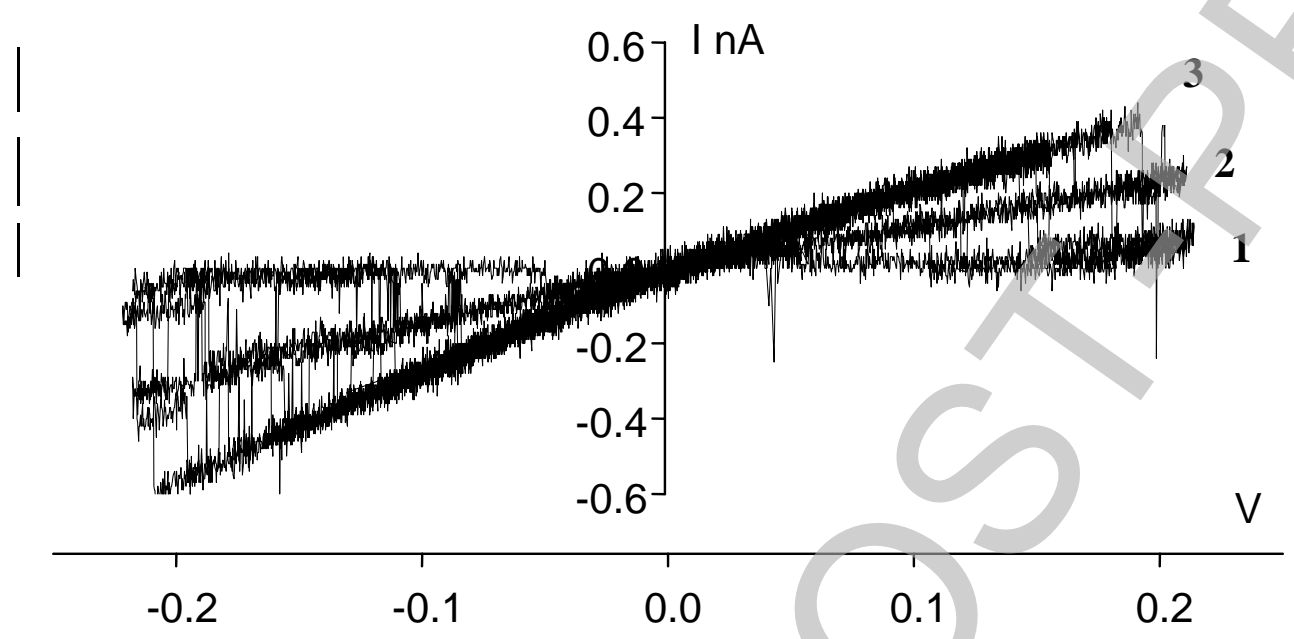




\section{Figure 6}

A

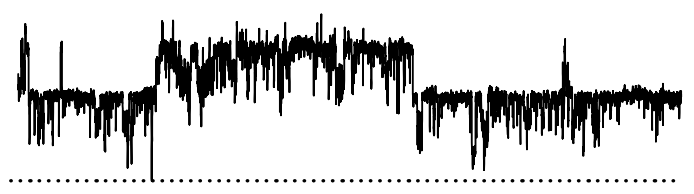

50 pA

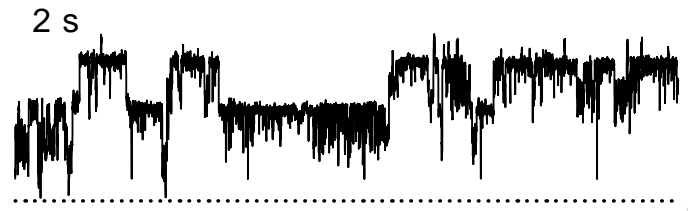

B
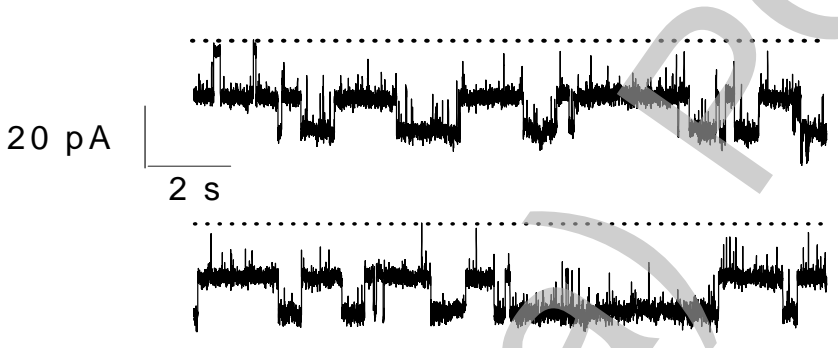